\title{
Interdisciplinary Approach: A Lever to Business Innovation
}

\author{
Jamil Razmak ${ }^{1} \&$ Charles H. Bélanger ${ }^{2}$ \\ ${ }^{1,2}$ School of Management, Laurentian University, Sudbury, ON, Canada \\ Correspondence: Jamil Razmak, School of Management, Laurentian University, Sudbury, ON., P3E 2C6, Canada. Tel: \\ $1-705-988-4233$
}

Received: March 6, 2016

Accepted: March 23, 2016

Online Published: March 28, 2016

doi:10.5430/ijhe.v5n2p173

URL: http://dx.doi.org/10.5430/ijhe.v5n2p173

\begin{abstract}
The advances in interdisciplinary studies are driving universities to utilize their available resources to efficiently enable development processes and provide increasing examples of research while gradually allocating the disciplines' resources. Ultimately, this trend asks universities to provide a platform of integrated disciplines, along with solid management to support the full-life cycle of interdisciplinary studies in fulfillment with internal policy and external regulations. To achieve this, we believe that this trend matches with business scholars to make a meaningful effort to show that their research thinking is interdisciplinary in nature. The key question is how business scholars, as professionals, provide the most value from academic disciplines in interdisciplinary research to solve real-life problems. Answering this question is accomplished in this study by using theoretical analysis to explore the concepts, benefits and uses of the existing knowledge base in interdisciplinary research as an innovative approach that links the business related-disciplines, people, and places involved to allocate universities' resources effectively.
\end{abstract}

Keywords: Interdisciplinarity, Innovation, Business research, E-health application, Change management

\section{Introduction}

An interdisciplinary approach is necessary for exploring the most critical challenges facing the world today, including business studies, socio-technological issues, societal problems, health care and education reform, and the fostering of innovation and knowledge (Aboelela et al., 2007; Lowe \& Phillipson, 2006; NIH, 2006; NSF, 2006). Fortunately, there is a wealth of informative literature in the field of interdisciplinary studies in the humanities and social sciences (Bromme, 2000; Klein, 2005; Lattuca, 2001; Mansilla \& Duraisingh, 2007; Newell, 2009a; Repko, 2009; Repko et al., 2011), the result of researchers' efforts to record and study information on such interdisciplinary academic activities such as courses, conferences, and scholarly publications over the course of many years.

Much of this 'knowledge base' is used to address those problems mentioned above. Indeed, interdisciplinarity is real life, it has been with us for a long time in all facets, and it was created to address both real-world problems and academic needs (Strathern, 2004, p.69). Nevertheless, interdisciplinary studies, like any new idea, has debates, both in favor of it and against it. According to its advantages, interdisciplinary studies have been developed and encouraged in a variety of situations, including problem-solving ability, synthesis of ideas and the integration of knowledge (Klein, 2000; Newell, 2007; Rafols et al., 2012; Repko, 2008), be they self-directed, creative or expressive (Gabelnick, 2002). Despite these advantages, interdisciplinary studies have been criticized by various scholars; for example, this approach, according to Benson (1982), lacks a coherent and defensible sense of purpose and has failed to check on the accuracy and validity of ideas or theories taken from other disciplines. As well, the success of interdisciplinary studies is often at political risk of resting on the benevolence of academic administrators, so much so that interdisciplinarians need always to advocate as defenders to explain the good aspects or features of the program that others must appreciate (Newell, 2009b; Wentworth \& Carp, 2009).

Nevertheless, it is useful to occasionally re-evaluate this knowledge base, taking into consideration new contributions along with transformations in thinking about the interdisciplinary approach. Because of this, the main objective of this study is to explore the benefits and uses of the existing knowledge base in this field to establish the interdisciplinary model as a research method and as an innovative approach, that links the business-related disciplines, people, and places involved. As a result, this study will apply and integrate these concepts to manage new knowledge and connect ideas, and to answer the study questions that have been shaped based on the real-world perspectives to be explored: 1) What is interdisciplinary research? 2) Why do business researchers need interdisciplinary research? 3) How can business researchers be engaged in interdisciplinary research? and 4) How 
can interdisciplinary research be done in business studies? The study's approach will be conducted according to the theoretical background of interdisciplinarity and its applications to the real world of academic research. Section one starts with a description of the basic concepts of disciplinarity, by illustrating its definitions in various contexts. Section two presents several concepts that are related to interdisciplinary studies: typologies, interdisciplinary learning, and research methods. Finally, this study will outline and address one practical application of interdisciplinary research within business studies.

\section{Disciplinarity in Business Studies}

The direction of such a study requires that we start thinking of the business disciplines and fields as the source of interdisciplinary studies. As we proceed, we must keep in mind that the concept of a discipline is not a straightforward one (Wray, 2003). In general, there are several meanings of discipline whether the language is Latin, English, or else., "but most of these meanings involve some notion of submission to a regularized set of practices, a sense of an imposed ordering of life and thought, body and mind" (Chandler, 2009). As a term, "discipline derives from the Latin words discipulus, which means 'pupil', and disciplina, which means 'teaching' (noun); related to it is also the word 'disciple' as in the disciples of Jesus" (Clarke, 2013; Krishnan, 2009). As a verb, it means training someone to follow a rigorous set of instructions, but also punishing and enforcing obedience (Clarke, 2013; Krishnan, 2009). The context in which the word discipline is used is important to academic institutions, philosophers, business, political and even social entities. In academic institutions, the term discipline refers to a particular branch of learning or body of knowledge whose defining elements-i.e., phenomena, assumptions, epistemology, concepts, theories, and methods - distinguish it from other knowledge formations (Moran, 2002; Repko, 2008;). That means disciplines can be identified at any point in time in terms of a bundle of phenomena studied, and theories and methods applied (Szostak, 2002a).

Focusing on specific words in defining the discipline of business studies may well create a debate in considering the various business sectors as a discipline or not. Historically, for example, Vickrey, (1970) has considered accounting as a measurement discipline, while Demski (2007) concluded that, at this time, accounting is not an academic discipline, but is "an ever-narrowing, insular vocational enterprise" (p.8); nevertheless, he further believes that eventually accounting could and should develop into a discipline. The debate also exists in information systems (IS) around the idea of whether IS should be a discipline, a science or a field. Khazanchi and Munkvold (2000) concluded that IS is "a scientific discipline in contrast to purportedly non-scientific fields" (p. 17). Moving in this direction, King (1993) asks, what the IS field is. His answer was "... information systems is probably not even a field [emphasis added], but rather an intellectual convocation that arose from the confluence of interests among individuals from many fields ...." (p.293). In other sectors, Hunt (1992) views marketing as an applied discipline, Grayson (2002) judges economics as a discipline and even now, some of the business-related disciplines are seeking to discipline themselves (Clark et al., 2016).

Generally, some disciplines would be considered to be more useful, more rigorous, more difficult, or more important than others (Vick, 2004). As well, some of them are conservative, averse to innovation, and resistant to change (Chettiparamb, 2007; Weingart \& Stehr, 2000). As a result, according to Chettiparamb, disciplines are drawing their boundaries too narrowly, restricting innovation and creativity, and limiting reflexivity and engagement with real-world problems, as well as with other disciplines. Implicitly, the appearance of interdisciplinarity may be seen as a response to the perceived limitations of disciplinarity (Chettiparamb, 2007; Klein, 2006; Shailer, 2005; Szostak, 2002b; Weingart \& Stehr, 2000). Finally, business disciplines need to develop the current situation and produce an innovative research that has the ability to develop Social Sciences and Humanities disciplines by integrating them and maximizing the give-and-take among them. Like any innovation, some people will welcome new development, while others will resist it by arguing that everything is right the way it is now (Chandler, 2009), but the nature of real-life problems with the flexibility of interdisciplinary studies will ultimately dominate. Therefore, the next section will explain interdiscplinarity concepts that address the flexibility of using interdisciplinary research by scholars in business studies.

\section{Interdisciplinarity}

The division of disciplines in various branches of universities sets the stage for later advancements in applying interdisciplinary studies to most subjects including business studies (Newell, 2008). Interdisciplinary studies have considerably changed the way that students and teachers do things, including completing their studies, research, and teaching. They are also an interesting approach that could become a goal for many universities, within different available programs and resources (Graybill \& Shandas, 2010). As well, interdisciplinary research has enabled scholars to navigate across disciplines, and help them move from purely academic problems to real-world issues 
(Carp, 2001). This will lead us to ask the following questions, with which interdisciplinarians often begin: What exactly is interdisciplinarity? Among the various concepts discussed in the literature - interdisciplinary research (National Academies, 2005), interdisciplinary understanding (Mansilla, 2010), interdisciplinary education (Rhoten $e t$ al., 2006), and interdisciplinary studies (Repko, 2008) - We prefer to use the interdisciplinary research definition which leads to a more adequate, richer conception of real-world problems.

That means there are several definitions to understand in the area of interdisciplinary studies. However, to present a foundation for a discussion of interdisciplinarity, Repko (2008) breaks down the word interdisciplinary into its two parts: 'inter' and 'disciplinary'. The prefix 'inter' means "between, among, in the midst;" disciplinary means "of or relating to a particular field of study" or specialization. So a starting point for the definition of "interdisciplinary" is "between fields of study" (Stember, 1991, p. 4). 'Inter' also means "derived from two or more." In terms of academic interdisciplinarity, several definitions advanced by academic institutions and scholars are involved. This definition is offered by the National Academy of Sciences, National Academy of Engineering, and the Institute of Medicine (2005):

"Interdisciplinary research is a mode of research by teams or individuals that integrates information, data, techniques, tools, perspectives, concepts, and/or theories from two or more disciplines or bodies of specialized knowledge to advance fundamental understanding or to solve problems whose solutions are beyond the scope of a single discipline or field of research practice" (p.26).

A second definition is offered by Aboelela et al. (2007). These authors have conducted a systematic literature review in three bodies of academic literature: business, education and healthcare. They reviewed 14 definitions of interdisciplinarity in 42 interdisciplinary research publications, as well, conducted 14 interviews with scholars to arrive at the following definition of interdisciplinary research:

"Interdisciplinary research is any study or group of studies undertaken by scholars from two or more distinct scientific disciplines. The research is based upon a conceptual model that links or integrates theoretical frameworks from those disciplines, uses study design and methodology that is not limited to any one field, and requires the use of perspectives and skills of the involved disciplines throughout multiple phases of the research process" (p.341).

These definitions draw on many concepts such as disciplinarity, integration, and the need for a more comprehensive understanding. Following the invention of the disciplines in past decades and centuries and the advances in interdisciplinary learning, integration allows for more comprehensive explanations, particularly due to the incorporation of disciplines' resources and the possible development of new metaphors to produce new knowledge (Repko, 2008). For example, the concept of entrepreneurship is a metaphor that coalesces with many other facets of business-related fields such as microfinance, innovation and human behaviour patterns.

\subsection{Typologies of Interdisciplinarity}

Scholars who conduct interdisciplinary research in business studies may or may not distinguish interdisciplinary typologies. For information purposes, the Organization for Economic Cooperation and Development (OECD) categorizes interdisciplinarity terms into "multidisciplinary," "interdisciplinary," and "transdisciplinary." Generally, to distinguish multidisciplinarity from interdisciplinarity, multidisciplinarity refers to the placing side-by-side of insights from two or more disciplines (Repko, 2008) and by aligning skills from these disciplines (Strathern, 2004, p.70). In addition, in the OECD classification, multidisciplinarity was defined as an approach that juxtaposes disciplines. Accordingly, even when disciplines and academic subjects are aligned, they are in a sequencing mode as well, or in a coordinating mode (Klein, 2010). This means that multidisciplinarity differs from interdisciplinarity in that the integration between or within disciplines has been reduced, contributions to individual disciplines are weaker, and there is less engagement with each discipline (Klein, 2010; Knight et al., 2013; Repko, 2008).

For those who also distinguish transdisciplinarity from interdisciplinarity, transdisciplinarity is "the application of theories, concepts, or methods across disciplines with the intent of developing an overarching synthesis" (Lattuca, 2001, p. 83). Strathern (2004, p.70) defined trandisciplinarity as "a kind of super-interdisciplinarity" which brings "disciplines together in contexts where new approaches arise out of the interaction between them, but to a heightened degree." In the OECD typology, transdisciplinarity (TD) was defined as a common system of axioms that transcends the narrow scope of disciplinary worldviews through an "overarching synthesis," such as healthcare, education, and manufacturing industries including construction and auto production (Klein, 2010). Insofar as transdisciplinarity differs from interdisciplinarity in theories, concepts, or methods, they are not borrowed from one discipline and applied to other disciplines that have the same problem (Repko, 2008). Rather, they transcend the narrow scope of disciplinary worldviews through an overarching synthesis (Klein, 2010, p.24). Regardless of the taxonomies of 
business sectors-- whether scholars consider accounting, marketing and IS as disciplines or not-- the flexibility in interdisciplinarity taxonomies transcends the narrow scope of these disciplines worldviews through an overarching synthesis.

\subsection{Reasons for Interdisciplinarity in Business Studies}

Generally, in the last century most of the Social Sciences and Humanities disciplines progressed slowly compared with the sciences. As well, because of the increased specialization and complexity in modern society, these disciplines may not be able to answer complex questions (Klein, 2010). Nevertheless, having an approach that offers what is needed when it is needed is critical for an academic decision maker to perform effectively in a challenging academic environment. Insofar as it is not sufficient for academia to offer just any approach, it must also offer better and more efficient ones to solve complex and real-world research problems. The real-world research problems that scholars address rarely arise within orderly disciplinary categories, and neither do their solutions (Palmer, 2001). The best solution for that is an interdisciplinary approach that our scholars need "to answer complex questions, solve complex problems, and gain coherent understanding of complex issues that are increasingly beyond the ability of any single discipline to address comprehensively or resolve adequately" (Repko, 2008, p.3).

Technology has also considerably changed the way human beings do things, including research and teaching. For example, the field of business and technology studies has an interesting intersection that would be possible with interdisciplinary ideas. The use of technologies in various branches of psychology and sociology (e.g. organizational behaviour and change management) sets the stage for later advancements in applying technology to Social Sciences and other disciplines such as business (Jasanoff, 2010). The merging of technology with communication is also a vital example for an integration process, which enhances interdisciplinary effectiveness. Additionally, the academic pressures of globalization make the interest in interdisciplinary research in business studies an urgent one. Success in this research will not be guaranteed just by teaching people with an interdisciplinary book or by knowing advantages and disadvantages of such choices. The business interdisciplinary research needs to play a part in improving its performance and productivity by removing silo mentalities and creating winning conditions to innovation.

\section{E-health Application, Change Management and Human Beings as an Interdisciplinary Problem in Business Research}

Any research method is a milestone followed by a systematic way of proceeding toward achieving its goal (Chandler, 2009). Interdisciplinarians such as Klein (2005) and Newell (2007) as well as Repko (2006, 2008) and Szostak (2002) have offered detailed steps, models, and examples in the conduct of interdisciplinary research with the caveat that no perfect work would ever use all of the possible outlined elements (Repko, 2006). However, interdisciplinary research should also provide measures of development and the nature of learning, as well as allocate goals that are better forecasters of students' academic requirements. Finally, using an empirical analysis of the systemic approach is very powerful in providing faculties with good information related to the learning patterns of both new and existing disciplines. Building on these models, the following section will apply Repko's research model to a case study that addresses practical life problems in business research.

\subsection{Drawing on Interdisciplinary Research Process Insights}

\section{Step 1: Define the Problem and Formulate the Focus Question}

Focused on North America (USA and Canada), this case will highlight specialized technology in the healthcare industry, resource allocations and government policy in the implementation process. This is related to governments forcing the implementation process of technology without considering all necessary factors. Focusing on e-health technology, for example, USA and Canada have paid billions of federal funds over the past decade to adopt an Electronic Medical Record (EMR) in their hospitals. To measure the adoption of EMR in hospitals, the Healthcare Information and Management Systems Society (HIMSS) uses a scale from 0, where no structures for EMR are in place, to 7, where EMR systems are fully functioning. In 2015, HIMSS reported that $17.3 \%$ of 641 hospitals in Canada were at stage 0 , and only $.02 \%$ were at stage 7 . In the USA, out of 5460 hospitals, only $2.1 \%$ are at stage 0 and $4.2 \%$ are at stage 7 (HIMSS, 2015). These numbers indicate that there is a complex problem somewhere in the implementation process of EMR.

According to these numbers, this case will address the following questions:

- Why does North America pay billions but ranks very low in the adoption of EMR?

- What are the human barriers to adopting EMR in North America?

- What are the strategies that should be adopted by the healthcare policy makers to lessen these barriers? 


\section{Step 2: Justify Using an Interdisciplinary Approach}

Many researchers are interested in interdisciplinary research because they know the limitations of disciplinary perspective, particularly, when they are dealing with complex and real-life research questions such as health care and health policy (Aboelela et al., 2007). Many justifications for poor innovation performance have been proposed over the years in numerous studies, but these studies have been limited by a lack of sufficient data and information (The Conference Board of Canada, 2013). As well, there are many justifications for using interdisciplinary research for this poor innovation performance. First, justification is focused on the complexity of this problem and questions that are proposed in this study, which relate to interdisciplinary definition (Newell, 2007, Repko, 2008). That means that a full understanding of innovative technology identity, policy, human perceptions, or knowledge can be achieved only by applying and integrating multiple perspectives and ways of thinking. As well, North America is a multicultural area with a mosaic of ethnic characteristics and the engagement of staff vis-a-vis the expansion of EMR has not received enough attention (Mort \& Finch, 2005). A second justification for the interdisciplinary approach occurs when important phenomena become part of the research problem and are also explored by more than one discipline. Because of this, various important phenomena and concepts concerning North America EMR become more difficult to fully comprehend when approached through the lens of a single discipline. Additionally, this case and other studies have to use a comparative analysis among North American hospitals to determine the impact of physiological, managerial, political and economic practices on the adoption of new technology.

Steps 3 and 4: Identify Relevant Disciplines and Conduct a Literature Search

Existing research has claimed that the adoption of EMR is affected by different factors and has also had considerable influence on staff practices. Besides these factors, management, technology, and economic policy are the primary disciplines in this research, but others (such as psychology and sociology) are employed in staff practices. As well, there are integration and overlapping between and within different disciplines and factors. In reality, psychological factors may overlap with the managerial factors (change management) particularly those that are related to human behaviour.

Steps 5 and 6: Develop Adequacy in Each Relevant Discipline, Analyze the Problem and Evaluate each Insight into it.

The overall perspectives of the related disciplines on EMR are described in the following:

- The psychological factors affecting staff attitudes to EMR

During the literature search, medical staff had discussed barriers to e-health by asking various questions concerning managerial and psychological behavioural perspectives. Their answers may lead to another motivating question that will be interacting with staff attitudes and practices in relation to economic factors, and so on. This means that e-health systems interact with other factors related to human perception, economic policy, and healthcare decision-making.

- The impact of managerial practices on the adoption of EMR

Organizational change is difficult because people cling to the existing systems. Many decision-makers boast about how important their staff are and how they consider them as human capital. Nevertheless, decision-makers have allocated resources towards acquiring new technologies rather than towards employee development. Changes in management and lack of management coordination may also affect the progress of this technology. For example, McCarter (2009) highlights that there are two agencies in charge of delivering the EMR- e-health Ontario and the Ministry's e-health Program Branch - neither of which, according to McCarter, coordinated or had productive working relationships. This was also a consequence of the lack of management coordination and strategic planning prior to the initiation of EMR- e-health projects (Aceti, 2010). As a result, the above has been problematic if not dysfunctional.

- The impact of political and economic practices on the adoption of EMR.

Interestingly, political influences have played a major role in the transition management and implementation of technology (Lang \& Mertes, 2011). For example, the Guardian News mentioned that the US government's shutdown of federal departments "would result in hundreds of thousands of federal workers being placed on unpaid leave, after House Republicans refused to pass a budget unless it involved a delay of Barack Obama's signature on healthcare reforms" (Lewis, 2013, p.14). This indicates that there are a significant number of factors that affect the scope of implemented e-health programs, such as interest group strength, party politics, economic variables and legislative professionalism (Schmeida et al., 2007). In Canada, some of these political issues rotate around the truth that 
e-health succeeds or fails depending on "decisions on access, coverage, spending, pricing, funding, and investment [which] are influenced by political incentives and these can often conflict with rational economic considerations" (Skinner, 2009, p.105). Along with that, the slow progress may also be related to economic factors such as the cost effectiveness of health technologies and health resources allocation (or dis-allocation).

- The impact of technological usability on the adoption of EMR

Many of the other factors recognized by previous studies are related to EMR adoption obstacles. The obstacles are reviewed through the FITT (Fit between Individual, Task and Technology) framework, developed by Ammenwerth et al. (2006). Many of the obstacles noted in previous literature still exist, such as software complexity, user acceptance, and so on. In addition, the obstacles recognized included computer-related characteristics, staff-related characteristics, and contextual characteristics (Whittaker, 2009). Furthermore, other obstacles imply inconsistencies between the software and procedural workflow. As a result, selected e-health components, and factors related to training, support, and maintenance may perhaps decrease some of these obstacles (Song et al., 2011).

Step 7: Identify Conflicts between Insights and Their Sources

There is no conflict in the same discipline but possible conflicts exist in some factors between disciplines, such as the fundamentals of assumption, concepts, and theories that are expressed as a disciplinary insight (Repko, 2008). The source of conflict is related to the nature of each discipline; for example, in this study the resistance and stress factors in the psychology discipline may conflict or overlap with the same factors in management discipline particularly when applying change management theory. However, the differences in disciplinary assumptions, factors, and theories related to e-health applications issues will determine the nature of conflict, integration or overlapping.

Steps 8 and 9: Create or Discover Common Ground and Integrate Insights

Common ground is created by modifying the concepts, assumptions and theories that are related to the slow progress of North America EMR technology. According to Repko (2008), common ground is not created by modifying the discipline's insights or perspectives. Due to this, creating common ground in this case may not be required between management and economics but between psychology, management, and technology. For example, this may be verified through producing an integrated behavioural model by integrating those disciplines; as a result, this model will modify the concepts and theories. This exactly matches with the integration description of Newell (2007): " Once common ground has been constructed, the modified insights can be integrated into a more comprehensive understanding of the complex problem...[which] should be responsive to each disciplinary perspective but beholden to none of them" (p. 257, 261).

\section{Step 10: Produce an Interdisciplinary Understanding of the Problem and Test It}

There are cognitive, affective and behavioral advancements in the comprehension of EMR technology with each discipline. The final step will be the testing of the interdisciplinary process; this will summarize the results of both qualitative focus groups and quantitative survey research; these include interviews, observations, and questionnaires. In order to carry out a technological assessment of the selected North America hospitals, related disciplines will be included in this case. The participants will be divided into three groups: knowledge workers, end users, and decision makers. This encapsulates the main ideas and purpose of this practical case.

\section{Conclusion}

Major innovations usually start with just one idea; then the idea grows and expands over time. As well, successful research goes through a chain of distinct steps; these steps should be worked through in sequence. In coming to this conclusion, interdisciplinarity benefited from a sequenced approach of discipline steps. Therefore, this study used a theoretical approach to show that interdisciplinary research matches with business scholars' knowledge and needs in this century. The study pursued a sequenced mode to give readers a sense of persuasion as a part of rhetorical analysis, starting from the concepts of interdisciplinarity, to why business scholars need interdisciplinarity and finally presenting a complete case on one important application. This sequenced approach will be used by new business interdisciplinarians in order to remove the challenges that face them in conducting interdisciplinary research. The first step focuses on helping business interdisciplinarians to understand the critical concepts in interdisciplinarity relating to their business sectors in multiple institutional settings. In the learning step, they will undertake procedures meant to shape their identities while simultaneously integrating them smoothly into an interdisciplinary research. This will be done when they remove the boundaries of their disciplines and fields, navigate between disciplinary concepts and theories that enable them to build a solid integration between these disciplines and solve complex problems. 
Another step is doing their interdisciplinarity research; this is very important, because it allows for the relation between disciplines, training for scholars, and integration of the interdisciplinary approach and other aspects of their beliefs, perspectives, and expectations. This allows for interdisciplinary research to build iteratively on previous disciplines' work. However, if we are using an iterative approach, the final step provides guidance in using that approach to effectively carry out the various steps in interdisciplinary research. The interdisciplinary application has been used in this study to confirm that interdicsiplinary research is oriented toward the needs of the community. The interdisciplinary approach is updated throughout a program's life cycle to reflect changes that affect the ongoing benefits of this approach. According to future and interdisciplinary trends, we believe that interdisciplinarity relies on a number of realties converging to make this trend successful. With the progress of thinking and technology, interdisciplinary studies in business sectors will show advanced modes of innovation and the ability to produce new ideas and better solutions. These will be the most obvious benefits. We now find ourselves in a new world with immediate academic effect, new trends and growing expectations that force scholars to conduct research by coordinating, integrating and using an overarching synthesis across disciplines.

\section{References}

Aboelela, S. W., Larson, E., Bakken, S., Carrasquillo, O., Formicola, A., Glied, S. A., ...Gebbie, K. M. (2007, February). Defining interdisciplinary research: conclusions from a critical review of the literature. Health Services Research, 42(1), 329+. $\quad$ Retrieved from http://go.galegroup.com/ps/i.do?id=GALE\%7CA159329857\&v=2.1\&u=subd78095\&it=r\&p=AONE\&sw=w\&a sid=bd2f2d2241465fdf50c40f8bffb4f2e6

Aceti, V. (2010). Exploring mHealth solutions: A case study on the influence of mHealth technologies on communication and information sharing at hamilton health sciences (Order No. MR73786). Available from ProQuest Dissertations \& Theses Global. (870326229). Retrieved from http://search.proquest.com/docview/870326229?accountid=12005

Ammenwerth, E., Iller, C., \& Mahler, C. (2006). IT-adoption and the interaction of task, technology and individuals: a fit framework and a case study. BMC medical informatics and decision making, 6(1), 3. Retrieved from http://dx.doi.org/10.1186/1472-6947-6-3

Benson, T. C. (1982). Five arguments against interdisciplinary studies. Issues in Integrative Studies, 1(1), 38-48.

Bromme, R. (2000). Beyond one's own perspective: The psychology of cognitive interdisciplinarity. Practicing Interdisciplinarity, 115-133.

Carp, R. M. (2001). Integrative praxes: Learning from multiple knowledge formations. Issues in Integrative Studies, 19(1), 71-121. Retrieved from http://citeseerx.ist.psu.edu/viewdoc/summary?doi=10.1.1.500.3117

Chandler, J. (2009). Introduction: Doctrines, disciplines, discourses, departments. Critical Inquiry, 35(4), 729-746. http://dx.doi.org/10.1086/599585

Chettiparamb, A. (2007). Interdisciplinarity: a literature review. HEA Interdisciplinary Teaching and Learning Group, Centre for Languages, Linguistics and Area Studies, University of Southampton. Retrieved from http://www.oakland.edu/upload/docs/AIS/interdisciplinarity_literature_review.pdf

Clarke, A. D. (2013). Lexicography and New Testament categories of church discipline. TYNDALE BULLETIN, 64, 130.

Clark, T., Ferrell, O. C., Hartline, M., Sheth, J., \& Stewart, D. (2016). Where/How Does Marketing Fit? What Is Marketing's Place in the Firm and Within the Family of Business Disciplines? In Let's Get Engaged! Crossing the Threshold of Marketing's Engagement Era (pp. 199-202). Springer. http://dx.doi.org/10.1007/978-3-319-11815-4_63

Demski, J. S. (2007). Is accounting an academic discipline? Accounting Horizons, 21(2), 153-157. http://dx.doi.org/10.2308/acch.2007.21.2.153

Gabelnick, F. (2002). Conclusion: achieving interdisciplinary innovation: leading and learning in community. In Innovations in Interdisciplinary Teaching, ed. C. Haynes, pp275-290. Washington, DC: American Council on Education/Oryx Press.

Graybill, J. K., \& Shandas, V. (2010). Doctoral student and early career academic perspectives, in: Frodeman, R., Thompson Klein, J., Mitcham, C., Holbrook, B., (Eds.), The Oxford Handbook of Interdisciplinarity. Oxford University Press, New York, pp. 404-418. 
Grayson, M. (2002). Economics as a Discipline. Critical Perspectives on Accounting, 13(5), 620. Retrieved from http://www.idealibrary.com on doi:10.1006/cpac.2002.0109

HIMSS - Healthcare Information and Management Systems. (2015). Electronic Medical Record Adoption Model. Retrieved from http://www.himssanalytics.org/provider-solutions

Hunt, S. D., Albaum, G., \& Lusch, R. F. (1992). Marketing is . . ; what is marketing? A comment on "marketing is . . ."; barriers to marketing becoming what it might be: Individual vs. community costs. Academy of Marketing Science. Journal, 20(4), 301. http://dx.doi.org/10.1007/bf02725205

Jasanoff, S. (2010). A field of its own: The emergence of science and technology studies. in: Frodeman, R., Thompson Klein, J., Mitcham, C., Holbrook, B., (Eds.), The Oxford Handbook of Interdisciplinarity. Oxford University Press, New York, pp. 191-205.

Khazanchi, D., \& Munkvold, B. E. (2000). Is information system a science? An inquiry into the nature of the information systems discipline. ACM Sigmis Database, 31(3), 24-42. http://doi.acm.org/10.1145/381823.381834

King, J.L. (1993). Editorial Notes. Information Systems Research, 4(4), 291-297. http://dx.doi.org/10.1287/isre.4.4.291

Klein, J. T. (2000). A conceptual vocabulary of interdisciplinary science. Practising interdisciplinarity, 3-24. in Weingart, P. and N. Stehr, editors. eds. Practising Interdisciplinarity Toronto University of Toronto Press.

Klein, J. T. (2005). Humanities, culture, and interdisciplinarity: The changing american academy State $\mathrm{U}$ of New York P. Retrieved from http://search.proquest.com/docview/742298212?accountid=12005

Klein, J. T. (2006). A platform for a shared discourse of interdisciplinary education. JSSE-Journal of Social Science Education, 5(4). Retrieved from http://www.jsse.org/jsse/index.php/jsse/article/view/1026

Klein, J. T. (2010). A taxonomy of interdisciplinarity. in: Frodeman, R., Thompson Klein, J., Mitcham, C., Holbrook, B., (Eds.), The Oxford Handbook of Interdisciplinarity. Oxford University Press, New York, pp. 15-30.

Knight, D. B., Lattuca, L. R., Kimball, E. W., \& Reason, R. D. (2013). Understanding interdisciplinarity: Curricular and organizational features of undergraduate interdisciplinary programs. Innovative Higher Education, 38(2), 143-158. http://dx.doi.org/10.1007/s10755-012-9232-1

Krishnan, A. (2009). What are academic disciplines? Some observations on the disciplinarity vs. interdisciplinarity debate. ESRC National Centre for Research Methods, NCRM Working Paper Series. Retrieved from http://eprints.ncrm.ac.uk/783/1/what_are_academic_disciplines.pdf

Lang, A., \& Mertes, A. (2011). E-health policy and deployment activities in Europe. Telemedicine and e-Health, 17(4), 262-268. http://dx.doi.org/10.1089/tmj.2010.0174

Lattuca, L. R. (2001). Creating interdisciplinarity: Interdisciplinary research and teaching among college and university faculty. vanderbilt issues in higher education Vanderbilt University Press, VU Station B 351813, Nashville, TN 37235-1813 (paperback: ISBN-0-8265-1383-2, hardback: ISBN-0-8265-1367-0, \$49.95). Retrieved from http://search.proquest.com/docview/62264140?accountid=12005

Lewis, P. (2013, September 29). US government shutdown: House votes to delay Obamacare law. The Guardian Newspaper, $\quad$ p14. Retrieved from http://www.theguardian.com/world/2013/sep/29/us-government-shutdown-house-delay-obamacare

Lowe, P., \& Phillipson, J. (2006). Reflexive interdisciplinary research: The making of a research programme on the rural economy and land use. Journal of Agricultural Economics, 57(2), 165-184. http://dx.doi.org/10.1111/j.1477-9552.2006.00045.x

Mansilla, V. B., \& Duraising, E. D. (2007). Targeted assessment of students' interdisciplinary work: An empirically grounded framework proposed. Journal of Higher Education, 78(2), 215-237. http://dx.doi.org/10.1353/jhe.2007.0008

Mansilla, V.B. (2010). Learning to synthesize: toward an epistemological foundation for interdisciplinary learning. in: Frodeman, R., Thompson Klein, J., Mitcham, C., Holbrook, B., (Eds.), The Oxford Handbook of Interdisciplinarity. Oxford University Press, New York, pp. 288-306.

McCarter, J. (2009). Ontario's Electronic Health Records Initiative. Toronto: Government of 134 Ontario. Retrieved from http://www.torontopubliclibrary.ca/detail.jsp?Entt=RDM2737301\&R=2737301 
$\begin{array}{lllll}\text { Moran, } & \text { J. } & \text { (2002). } & \text { Interdisciplinarity Routledge. } & \text { Retrieved }\end{array}$ http://search.proquest.com/docview/1321788357?accountid=12005

Mort, M., \& Finch, T. (2005). Principles for telemedicine and telecare: The perspective of a citizens' panel. Journal of Telemedicine and Telecare, 11(suppl 1), 66-68. http://dx.doi.org/10.1258/1357633054461877

National Academies Committee on Science Engineering and Public Policy (COSEPUP) Committee on Facilitating Interdisciplinary Research. 2005. Facilitating interdisciplinary research. Washington, DC: National Academies Press.

Newell, W. H. (2001). A theory of interdisciplinary studies. Issues in Integrative Studies, 19(1), 1-25. Retrieved from https://www.researchgate.net/profile/William_Newell/publication/238490809_A_Theory_of_Interdisciplinary_ Studies/links/004635314bfc74acf6000000.pdf

Newell, W. H. (2007). Decision making in interdisciplinary studies. Public Administration and Public Policy-New York-, 123, 245. Retrieved from http://www.crcnetbase.com/doi/abs/10.1201/9781420016918.ch13

Newell, W. H. (2008). The intertwined history of interdisciplinary undergraduate education and the Association for Integrative Studies. Issues in Integrative Studies, 26, 1-59. Retrieved from https://www.researchgate.net/profile/William_Newell/publication/260629870_The_Intertwined_History_of_Int erdisciplinary_Undergraduate_Education_and_the_Association_for_Integrative_Studies_An_Insider's_View/lin ks/02e7e531dc454c578c000000.pdf

Newell, W. H. (2009a). Interdisciplinarity in undergraduate general education. in: Frodeman, R., Thompson Klein, J., Mitcham, C., Holbrook, B., (Eds.), The Oxford Handbook of Interdisciplinarity. Oxford University Press, New York, pp. 360-371.

Newell, W. H. (2009b). "The Political Life Cycle of a Cluster College: The Western College Program at Miami University." Politics of Interdisciplinary Studies: Essays on Transformations in American Undergraduate Programs. Ed. Tanya Augsburg and Stuart Henry. Jefferson, NC: McFarland, 29-50. Print.

NIH. National Institutes of Health. (2006). NIH roadmap for medical research. Bethesda, MD: Author.

NSF. National Science Foundation. (2006). National Science Foundation investing in America's future strategic plan FY 2006-2011 (No. NSF 06-48). Arlington, VA: Author.

Palmer, C. L. (2001). Work at the boundaries of science: Information and the interdisciplinary research process. Springer Science \& Business Media. http://dx.doi.org/10.1007/978-94-015-9843-9

Rafols, I., Leydesdorff, L., O’Hare, A., Nightingale, P., \& Stirling, A. (2012). How journal rankings can suppress interdisciplinary research: A comparison between innovation studies and business \& management. Research Policy, 41(7), 1262-1282. http://dx.doi.org/10.1016/j.respol.2012.03.015

Repko, A. F. (2006). Disciplining interdisciplinarity: The case for textbooks. Issues in Integrative Studies, 24, $112-142$

Retrieved

from http://www.oakland.edu/upload/docs/AIS/Issues\%20in\%20Interdisciplinary\%20Studies/2006\%20Volume\%202 4/06_Vol_24_pp_112_142_Disciplining_Interdisciplinarity_The_Case_for_Textbooks_(Allen_Repko).pdf

Repko, A. F. (2008). Interdisciplinary research; process and theory, 2d ed. (2011, December). Reference \& Research Book News, 26(6). $\quad$ Retrieved from http://go.galegroup.com/ps/i.do?id=GALE\%7CA274120700\&v=2.1\&u=subd78095\&it=r\&p=AONE\&sw=w\&a sid=79ee2c1fdcc32a2721269b9c18b77497

Repko, A. F. (2009). Transforming an Experimental Innovation into a Sustainable Academic Program at the University of Texas-Arlington. T. Augsburg \& S. Henry The politics of interdisciplinary studies: Essays on transformations in American undergraduate programs. Jefferson, NC: McFarland.

Repko, A. F., Newell, W. H., \& Szostak, R. (2011). Case studies in interdisciplinary research. Reference \& Research Book News, 26(2). $\quad$ Retrieved from http://go.galegroup.com/ps/i.do?id=GALE\%7CA253496155\&v=2.1\&u=subd78095\&it=r\&p=AONE\&sw=w\&a sid=cf25e545583b39e7de2bf7a7d2f2f403

Rhoten, D., Boix Mansilla, V., Chun, M., \& Klein, J. T. (2007). Interdisciplinary education at liberal arts institutions. New York: $\quad$ Teagle $\quad$ Foundation. $\quad$ Retrieved from http://www.teaglefoundation.org/learning/pdf/2006_ssrc_whitepaper.pdf 
Schmeida, M., McNeal, R., \& Mossberger, K. (2007). Policy determinants affect telehealth implementation. Telemedicine and E-Health, 13(2), 100-107. http://dx.doi.org/10.1089/tmj.2006.0017

Shailer, K. (2005). Interdisciplinarity in a Disciplinary Universe: a Review of Key Issues, Discussion paper. Retrieved from http://www.cou.on.ca

Skinner, B. J. (2009). Canadian Health Policy Failures: What's Wrong? Who Gets Hurt? Why Nothing Changes. The Fraser Institute. Retrieved from https://www.fraserinstitute.org/sites/default/files/CanadianHealthPolicyFailures2009.pdf

Song, P. H., Scheck McAlearney, A., Robbins, J., \& McCullough, J. S. (2011). Exploring the business case for ambulatory electronic health record system adoption. Journal of Healthcare Management, 56(3), 169. Retrieved from http://www.ncbi.nlm.nih.gov/pubmed/21714372

Stember, M. (1991). Advancing the social sciences through the interdisciplinary enterprise. The Social Science Journal, 28(1), 1. http://dx.doi.org/10.1016/0362-3319(91)90040-B

Strathern, M. (2004). Commons and borderlands: Working papers on interdisciplinarity, accountability and the flow of knowledge. Sean Kingston Pub.

Szostak, R. (2002a). How to do interdisciplinarity: Integrating the debate. Issues in Integrative Studies, 20, 103-122. Retrieved from https://era.library.ualberta.ca/downloads/9c67wp539

Szostak, R. (2002b). Intuition and interdisciplinarity: A reply to Mackey. Issues in Integrative Studies, 20, 131-137. Retrieved from https://www.oakland.edu/upload/docs/AIS/Issues\%20in\%20Interdisciplinary\%20Studies/2002\%20Volume\%20 20/09_Vol_20_pp_131_137_Intution_and_Interdisciplinarity_A_Reply_to_Mackey_(Rick_Szostak).pdf

The Conference Board of Canada. (2013). How Canada Performs: A Report Card on Canada-assesses Canada's quality of life compared with that of its peer countries. Retrieved from http://www.conferenceboard.ca/Libraries/PUBLIC_PDFS/13-260_HCP2013_ExecSumm.sflb

Vick, D. W. (2004, June). Interdisciplinarity and the discipline of law. Journal of Law and Society, 31(2), 163-193. http://dx.doi.org/10.1111/j.1467-6478.2004.00286.x

Vickrey, D. W. (1970). Is accounting a measurement discipline? The Accounting Review, 45(4), 731-742.

Weingart, P., \& Stehr, N. (Eds.) (2000). Practising interdisciplinarity. Toronto: University of Toronto Press.

Wentworth, J., \& Carp, E. M. (2009). 'Phoenix: From Ashes to Reincarnation at Appalachian State University. The Politics of Interdisciplinary Studies: Essays on Transformations in American Undergraduate Programs. Jefferson, NC: McFarland.

Whittaker, A. A., Aufdenkamp, M., \& Tinley, S. (2009). Barriers and facilitators to electronic documentation in a rural hospital. Journal of Nursing Scholarship, 41(3), 293. http://dx.doi.org/10.1111/j.1547-5069.2009.01278.x

Wray, K. B. (2003). Review of: Academic tribes and territories: Intellectual enquiry and the culture of disciplines (second edition). International Studies in the Philosophy of Science, 17(3), 317-319. Retrieved from http://search.proquest.com/docview/43083565?accountid=12005 